\title{
Policy of Ulama Consultative Council in Government Politics at Lhokseumawe
}

\author{
Muhammad $^{1}$, Sukiman $^{2}$, Irwansyah $^{2}$ \\ ${ }^{I}$ Ph.D Student in State Islamic University of North Sumatera (UINSU), Medan, Indonesia \\ ${ }^{2}$ Lecturer in State Islamic University of North Sumatera (UINSU), Medan, Indonesia \\ Sagmuhammad@yahoo.com
}

\begin{abstract}
The aim of this research is to know the roles and the functions of Ulama Consultative Council in Government at Lhokseumawe, Aceh, Sumatera. The method is used qualitative research to get and to develop the data and result. The result is found that the role of the Ulama Consultative Council in government politics in Lhokseumawe City can be grouped into two forms, namely the role of consideration and function in establishing legal edicts. Ulama Consultative Council functions optimally in providing consideration / suggestions / suggestions to local governments. The function of determining legal edicts, where Ulama Consultative Council oversees the administration of government, development and community development, then the results of supervision can be issued in the form of legal edicts submitted to local governments and also disseminated to the public.
\end{abstract}

Keywords

Uamaconsultativecouncil;

politic, roleandfunction

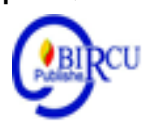

\section{Introduction}

A cleric is required to be able to understand the social development of society. So for the modern world now, scholars are not only required to simply understand the books of science of jurisprudence, commentaries or hadith that already existed especially in the form of rote memorization. To answer the challenges and problems of the present and the future, a complete and dynamic mastery of Islamic sciences and related aids is needed, and insights are also needed to help reason in understanding the development of society. Thus, scholars can always provide guidance and direction that is appropriate, accepted by the community and not entangled in a static understanding of religion and narrow insights and is also included in the field of government policy.

Inspirationally Qur'an indeed encourages Muslims to advance, especially in exploring and developing knowledge. For example, there are many verses that mention astronomy, biology, physics, history, geography and so on, as a sign of God's greatness and power that must be investigated by humans. History also notes that Muslims have succeeded in developing science in the middle century, all of which are thanks to the encouragement of Qur'an

In accordance with the demands of the situation, an Ulama should not hold to just one interpretation of Qur'anic verse which is the product of the opinion of a living scholar that is not exactly the same as the current atmosphere of social progress and knowledge, but Ulama is now required to try to develop the principles contained in Islamic teachings for Managing challenges that are always dynamic and changing. This does not mean that the Koran simply recognizes the development of society, but in accordance with its function the Koran gives guidance to the people, then this book should be used as a stimulus and accommodator of positive developments that occur in society. Scholars must be able to provide guidance and 
guidance that directs the development of modern culture or technology as sophisticated as any.

There are times when those who argue that a legislative issue in a country is a task is assigned to Ulama. There are even those who give even more dominant power to Ulama, namely their duty not only to make laws, but also to be able to veto plans of laws recommended by the legislative body or the government, if the plans of these laws contradict the beliefs held by Ulama. This assumption happened because they considered Ulama to be a group that understood more than the community groups so that they were considered like a group of people who were slightly higher (elite) in rank than ordinary people. In addition, Ulama group often gets more respect in Islamic societies compared to other community groups so that in certain societies, it is felt that Ulama have more standing rights than ordinary people.

Apart from the fact of public respect for Ulama and its consequences in the political field, Ibn Taymiyah gave a dual role to Ulama. In the ranks of Ulama power entrusted with the dual function of interpreting sharia laws and formulating the administration of justice. In this case, Ibnu Taymiyah's concept of understanding is understood that Ulama are included in the formulating group of laws. While Umara (government) is entrusted with the task of carrying out the enactment of the laws. These two groups, Ulama and Umara, according to Ibn Taymiyah, are described by Qur'an as uliy al-amri.

\section{Review of Literature}

\subsection{The Position of Ulama during the Islamic Glory in Aceh The Age of the Islamic Kingdom \\ a. The Pasai Sultanate}

The Pasai Kingdom is a large kingdom, the center of trade and the development of Islam. As a big kingdom, in this kingdom also developed a life that produces good writing. A creative minority group succeeded in utilizing Arabic letters brought by Islam, to write their work in Malay. This is what came to be called Jawi, and the letters are called Jawi Arabic. Among the papers is Hikayat Raja Pasai (HRP). The initial part of the text is estimated to have been written around 1360 AD HRP marked the start of the development of classical Malay literature on the archipelago. The Malay language was then also used by Shaykh Abdurrauf al-Singkili to write his books. In line with that, also developed Sufism. Among the books of Sufism translated into Malay is Durru al-Manzum, by Maulana Abu Ishak. This book was then translated into Malay by Makhdum Patakan, at the request of the Sultan of Malacca. The information above tells a bit of the role that Samudera Pasai had played in its position as the center of Islamic civilization in Southeast Asia at that time.

Since the founding of the Islamic Kingdom in Pasai, (1270 AD) Acehnese scholars have begun to play an important role in the kingdom. They served as advisers to the king in charge of the religious and sultanate of Pasai. The involvement of Ulama in the kingdom as quoted by M. Hasbi Amiruddin from The Malay Annals, has made the kingdom a reference and role model for other Islamic kingdoms in the field of religion. Every problem that is not clear or in a problem there are different views about Islamic teachings and practices, the problem is left to be decided at Pasai. In Malay History, it was stated that although Malacca had grown into a great kingdom, its leaders remained in contact with Pasai, especially when it needed decisions relating to Islam both in theory and practice. Malik al-Salih, who founded Pasai Kingdom, had asked to bring in some scholars from Makkah and other places in order 
to teach Islamic teachings to the people. He himself, often discussing with scholars about the teachings of Islam. In the palace, he placed several scholars from Makkah, Persia and India and chose one of them as a royal adviser. Ibn Bathuthat mentions two great scholars who worked in the Sultanate of Pasai (659 / 1260-913 / 1507) from Persia during the reign of alMalik al-Zhahir II (727 / 1326-749 / 1348), namely Amir Sa'id from Shiraz who holding the position of religious judge (qadhi) concurrently a religious teacher, and Tajuddin from Ishfahan as a mufti and concurrently a religious teacher.

In the era of the Pasai Sultanate as well, the role of Acehnese scholars was able to bring Aceh's name to the world. This achievement occurred at the time of the Sultan of Malacca in power, when there were differences of opinion among scholars from Bukhara and Samarkand and scholars from Khurasan and Iraq on two opinions relating to theological aspects. First, related to the words, "man qala Allahu ta'ala khaliqun wa raziqun fi al-azali kafara faqad." This means that whoever says Allah Ta'ala is the creator and provider of sustenance since the time of the azali, he is considered to have been infidels ", secondly, "Man qala innallaha ta'ala lam yakun khaliqan wa raziqan fi al-azali kafara faqad." Meaning, "Whoever says God is not the Creator and Provider of fortune since the time of azali then he is also considered to be an infidel".

To find the answer, the Sultan of Malacca had sent a representative of Aceh's Ulama in Pasai. Representing the Acehnese Ulama, Sultan Pasai gave a satisfying answer, so that the problem could be resolved properly.

\section{b. The period of the Sultanate of Aceh Darussalam}

Iskandar Muda who ruled the Islamic Kingdom of Aceh Darussalam (1607-1636 AD) chose Syam al-Din al-Sumatrani as his adviser and muftì known as "shaykh al Islam". He is the highest responsible in religious affairs. Even so, al-Sumatrani was not only a religious adviser, but was also sometimes involved in political affairs. Al-Sumatrani's involvement in royal affairs has occurred since Sultan Ali Mughayat Syah (1589-1602 AD) king before Iskandar Muda. James Lancaster, special envoy from England to Aceh in 1602 AD Describes in his travel notes that there was a noble "chief bishop", who was thought to be Al-sumatrani, who was involved in negotiating a peace and friendship treaty between Britain and Aceh.

Nur al-Din al-Raniri was chosen as Qāộ̄ al-Malik al-ildil and Muftī Mu'azzam in the period of Sultan Iskandar Thani and the next few years the leader was the iatafiat al-Din. AlRaniri is described in a number of historical chapters of Aceh as a great person. He is basically not only a Sufi, theologian and jurisprudent, but he is also an author, advisor and politician. During Iskandar Thani's time, he played an important role in the fields of economics, politics as well as being responsible for religious matters.

When describing the glory of Aceh under the empire of the queens, A. Hasjmi stated that Sheikh Abd al-Rauf al-Singkili was designated as muftī and Qāọ̄i al-Malik al-'Ādil of the Islamic Kingdom of Aceh during the four queen period (1641-1699 CE) leading the kingdom . Sultānah who chose her to be a muftī was Tāj al-'Ālam Safiat al-Din (1641-1675 AD), wife and successor to Iskandar Thani and was the first queen. The next Sulțānah is Nur al-Ālam Naqiyyqt al-Din who led only 3 years and died on January 23, 1678. The next Sultānah was her own son Inayah Syah Zakiyyat al-Din who ruled the Kingdom of Aceh for 10 years. After he died in 1688 Keumalat Syah was replaced as the fourth Sulțānah and was the last Sulțānah to lead the Islamic Kingdom of Aceh. After leading for about 10 years he was demoted from power in 1699. 
Al-Singkili, besides being a cleric, is also a figure who is often known to be involved in political affairs. He played a role in resolving conflicts, for example, when a delegation sent by Syarīf Makkah to Aceh during the Sulțānah Zakiyyah al-Din at the request of some Acehnese leaders who questioned the issue of women's permissibility as a leader according to al-Singkililah Islamic law accepted them. Furthermore, M. Hasbi, citing several sources, gave a description of the debate about the leadership of women who had invited very long differences of opinion within the community in Aceh. In this case, al-Singkili did not give a firm answer on the matter. Al-Singkili's attitude thus gives an understanding that he supports the leadership of women for certain reasons. Thus, while al-Singkili was still alive, no group dared to challenge Sultānah's authority. He worked for 50 years under the leadership of women, perhaps because of that, his name became a symbol of the authority of the Ulama in Aceh as is often mentioned in Acehnese proverbs: "Adak like Poteumeureuhom, Hukom like Syiah Kuala" (Adat Affairs of the King, Religion Ulama affairs).

\section{Discussion}

Ulama consultative Council considerations conveyed to the Regional Head to what extent have binding power. According to the prevailing norm if the advice is received, that is, the consideration given to the Regional Head, it proves that Ulama consultative Council is partly responsible for the policy of the Regional Head implemented, based on his considerations. This problem is complicated because Ulama consultative Council does not have enough officials to be able to observe all Regional Head's policies that have been implemented in line with consideration given. Because Ulama consultative Council does not have enough officials, the responsibility of Ulama consultative Council for the considerations given to the Regional Head is difficult to monitor. The important thing is that the function or task of Ulama consultative Council has been carried out even though it is not entirely accepted by the Regional Head. Whether or not Ulama consultative Council's considerations are accepted is the moral responsibility of the Regional Head for attention.

Furthermore, the attachment of the Regional Head to Ulama consultative Council's consideration is strongly influenced by three aspects, namely: First, the Regional Head is bound because he is required by statutory provisions; Second, the awareness of the Regional Head himself as the administration of responsible government in accordance with the general principles of proper governance; Third, the attachment of the Regional Head due to the quality of the consideration itself, which causes the Regional Head no other choice not to accept these considerations.

Regarding the existing normative provisions, up to now there has not been a single legislation that regulates the obligation for the Regional Head to heed any considerations submitted by Ulama consultative Council and the Regional Head's obligation to ask the Ulama consultative Council in goverment politics at Lhokseumawe. These are all the rights of the Regional Head, in other words whether his rights will be used or not used, it is entirely up to the Regional Head. In the case that the Regional Head uses his right to ask the Ulama consultative Council. Ulama consultative Council as a body of judgment for the Regional Head is obliged to answer or provide considerations as required by Regional Head and The House of Representative. Instead Ulama consultative Council's status as an equal partner of the executive and legislative regions is obliged to submit suggestions, to the executive and legislative branches, even though there is no obligation to accept them. It really depends on the thinking of The Regional Head and Regional People's Representative Assembly itself, 
whether or not Ulama consultative Council in Goverment Politics at Lhokseumawe's consideration is accepted as the basis of policy in the administration of Regional Government.

Thus, it is clear that Ulama consultative Council is obliged to provide suggestions and answer every question of the Regional Head and has the right to submit proposals to the Regional Head regarding all matters concerning the implementation of Regional Government. In this case the question arises as to what arises, if Ulama consultative Council does not have the initiative and obligation to submit suggestions and vice versa the Regional Head never asks. Such conditions certainly result in the objective of implementing the Regional Government not being achieved as expected, or at least the running of the Regional Government falters. This is because there are no legal provisions that require / require the Regional Head to ask questions and make every consideration submitted by the Ulama Consultative Council to him as the basis of his policy. The Regional Head is the organizer of the government, both morally and legally obliged to heed, obey the normative provisions that contain the principles contained therein as the basis for the administration of the principles. These principles are general principles of government that are worthy of the truth that are the foundation of thought and became the basis of the State Administrative Law. The implementation of general principles of proper governance is a benchmark or an effort to assess which government actions are good and should be carried out by the Regional Head.

Therefore, every state official is obliged to take an oath based on his belief which is a moral guarantee not to deviate from carrying out his obligations. If holding on to these matters, the Regional Head is indirectly bound to heed or pay attention to the considerations conveyed by Ulama Consultative Council in Government Politics at Lhokseumawe.

If you look at and analyze the findings of the above research on how political views and efforts of the Ulama in Lhokseumawe City and based on the classification of the place where the Ulama (organization) is housed, it is clear that their views and ideas in resolving various political confusion, both political dressed in conflict and political governance shows that all input efforts given by Ulama in Lhokseumawe City are inseparable from their organizational background.

In this case it is clearly seen how the efforts carried out by Ulama Consultative Council who are more likely to involve / politicize the government system by becoming partners and advisors and issuing policies and fatwas, this certainly cannot be said Ulama Consultative Council is an underdog partner or splinter of a government system However, Ulama Consultative Council remains an organization of independent and neutral Ulama organizations.

The Ulama Consultative Council in Goverment Politics at Lhokseumawe's function in government politics can be grouped into two types of functions, namely the consideration function and the function of establishing legal edicts. Ulama Consultative Council functions optimally in providing consideration / suggestions / suggestions to local governments. The function of determining legal edicts, where Ulama Consultative Council in Goverment Politics at Lhokseumawes oversee the administration of government, development and community development, then the results of supervision can be issued in the form of legal edicts submitted to local governments and also disseminated to the public. The most obvious thing about its appeal regarding political issues, especially in the Lhokseumawe area which is accommodated by Ulama Consultative Council in Goverment Politics at Lhokseumawe, is about the issue of the implementation of the General Election, as stated in the following policy formulation: 
a. That the problem of government and state life is a very basic and regulated problem in Islam;

b. That the Regional Head Election is part of the demands of the Islamic religion to choose a good state organization in an effort to implement Islamic Sharia, bring about peace, prosperity, and prosperity for the entire community;

c. that for the implementation of good governance, it is necessary to uphold Islamic Sharia values and the active role of the community optimally;

d. that for this purpose, the ULAMA CONSULTATIVE COUNCIL deems it necessary to issue taushiyah on the General Election, among others:

1) Calling on all citizens of the Republic of Indonesia in Lhokseumawe City to exercise their right to vote in the Regional Election on April 9, 2012 as well as possible.

2) Every Muslim is required to choose people who are pious, honest, angry, intelligent, knowledgeable, communicative and have a high commitment to the application of Islamic Shari'ah in a kaffah.

3) Calling on KIP, PANWASLU, and all parties responsible for organizing regional elections for regional heads to act honestly and fairly and to maintain order, security and peace.

4) Inviting all citizens of the Republic of Indonesia in Lhokseumawe City to continue to maintain unity and integrity and maintain ukhuwah for the maintenance of lasting peace.

5) Expect candidates and their success teams not to slander, money politics, intimidation and other things that are contrary to Islamic Sharia.

6) Expect candidates and their success teams to accept the results of regional head elections with full sincerity, and if disputes occur so that they can be resolved by deliberation and consensus in accordance with applicable laws.

Policy Normatively Ulama Consultative Council considerations conveyed by regional heads are not bound, but are strongly influenced by the awareness of regional heads as responsible governance in accordance with general principles of proper governance and the quality of considerations conveyed by Ulama Consultative Council which causes regional heads to have no other choice not to accept it. To realize Ulama Consultative Council In Goverment Politics At Lhokseumawe's function as a partner in line with the local government and DPRD, there needs to be strict provisions in the qanun, so that the significance of the position of the Ulama Consultative Council In Goverment Politics At Lhokseumawe's relationship with other regional institutions in the implementation of special autonomy, so that there is no opportunity to ignore the Ulama Consultative Council Institution.

Unlike the case with HUDA Ulama who are more active in dialoguing the conflicting elements, they can directly portray themselves as mediators. The role of mediation is clearly seen in each person of HUDA Ulama, this is also due to one of them because the Ulama gathered in this HUDA organization are mostly bases and the position is directly in the midst of the community, such as in Dayah and Islamic Boarding Schools. So the role they play is also directly in touch with all the problems of society such as fighting and political conflicts that occur in the Lhokseumawe region.

HUDA Ulamas sometimes do not want to appear too forward, because they do not want to get publications like celebrities, but the carrying of low provile HUDA Ulama with human values makes it easier for HUDA scholars to establish communication with various parties. The role of HUDA scholars can be through the Acehan moral and cultural approach in a 
different nuance. The role of HUDA scholars like this sometimes is not immediately felt in the near future, but its effectiveness is felt.

Some historical events that occurred in Aceh in general and in Lhokseumawe region as the basis of the Aceh conflict in particular, showed the effectiveness of the role of HUDA scholars in resolving political conflicts. HUDA Ulama is one group that is trusted by the community and also the government. HUDA Ulama is part of the constituent group and the driving force which is one part of the law governing the Aceh peace process. Negotiations and meetings with the parties to the conflict also involved representatives of HUDA scholars. It is clearly seen that the HUDA Ulama are a very potential group in playing political communication in the process of conflict resolution and initiation towards peace, as a respected group in society. Optimizing the role and communication of HUDA scholars is one of the efforts that can be done because politics itself is part of the implementation of the Islamic concept itself, where HUDA scholars are an important part that cannot be separated.

\section{Conclusion}

The role of the Ulama Consultative Council in government politics in Lhokseumawe City can be grouped into two forms, namely the role of consideration and function in setting legal edicts. Ulama Consultative Council functions optimally in providing consideration / suggestions / suggestions to local governments. The function of determining legal edicts, where Ulama Consultative Council in Goverment Politics oversee the administration of government, development and community development, then the results of supervision can be issued in the form of legal edicts submitted to local governments and also disseminated to the public. Normatively Ulama Consultative Council considerations conveyed by regional heads are not bound, but are strongly influenced by the awareness of regional heads as responsible governance in accordance with general principles of decent governance and the quality of considerations conveyed by Ulama Consultative Council which causes each element and unit in the City government Lhokseumawen must choose to accept it. In order to realize the Ulama Consultative Council in Goverment Politics at Lhokseumawe's function as a partner in line with the local government and DPRD, strict provisions are made in the qanun, so that the relationship between The Ulama Consultative Council and other regional institutions in the implementation of special autonomy is clear, so that there is no opportunity to neglect the Ulama Consultative Council institutions, especially their involvement in government politics.

\section{References}

Abdullah, Taufik. 1987. Islam dan Masyarakat; Pantulan Sejarah Indonesia. Jakarta: LP3ES.

Abu Bakar, Alyasa\& Abdullah, Wamad. 1992. "Manuskrib Dayah Tanoh Abee, Kajian Keislaman di Aceh pada Masa Kesultanan,” dalam Kajian Islam, no. 2.

Alfian, Ibrahim. 1987. Perang di Jalan Allah. Jakarta: Pustaka Sinar Harapan. 1999. Aceh Dalam Lintasan Sejarah. Yogyakarta: Gadjah Mada Universty Press.

Al-Chaidar, GAM. 1999. Jihad Rakyat Aceh Mewujudkan Negara Islamh. Jakarta: Madani Press.

Al-Syiraziy. 1994. al-Muhadhdhab, juz II. Beirūt Dār al-Fikr.

Amiruddin, Muhammad Hasbi. 2003. Ulama Dayah Pengawal Agama Masyarakat Aceh. Lhokseumawe, Nadiya Foundation. 
1999..Konsep Negara Islam Fazlur Rahman, Desertasi. Jakarta: Pps IAIN Syarif Hidayatullah.

Azra, Azyumardi.1995. Jaringan Ulama Timur Tengah dan Kepulauan Nusantara abad 17-18 Bandung: Mizan.

Baihaqi A.K. 1983. Agama dan Perubahan Sosial . Jakarta: Rajawali Press.

Brown, C.C. 1976. Sejarah Melayu; The Malay Annals. Oxford: Oxford University Press.

Beurdan, Teungku Haji Ibrahim. 2008. Resolusi Konflik Dalam Islam: kajian Normatif dan Historis Perspektif Ulama Dayah. Banda Aceh: Aceh Institute Press.

Daudy, Ahmad. 1983. Allah dan Manusia dalam Konsepsi Syeikh Nuruddin Ar-Raniri. Jakarta: Rajawali.

Gaharu, Syamaun. 1991. Aceh Wawasan Nasional dan Terobosan Pembangunan. Banda Aceh: Pemda Aceh.

Haji Abdul Malik Karim Amrullah (HAMKA). 1981. Sejarah Umat Islam, Cet. III. Jakarta: Bulan Bintang.

1982. Dari Perbendaharaan Lama. Jakarta: Pustaka Panjimas.

Hasjimi, Ali. 1983. 59 Tahun Aceh Merdeka di Bawah Pemerintahan Ratu. Jakarta: Bulan Bintang.

1871. Hikayat Perang Sabi Menjiwai Perang Aceh Lawan Belanda. Banda Aceh: Pustaka Farabi.

--.1991. Sejarah Kebudayaan Islam di Indonesia. Jakarta: Bulan Bintang.

Idris, Safwan. 1995. Perkembangan Pendidikan Pesantren/Dayah (Antara Tradisi dan Pembaruan) dalam "Pendidikan di Daerah Istimewa Aceh". Banda Aceh: Majelis Pendidikan Daerah Istimewa Aceh.

Isa, A. Gani. 2001. Ulama Aceh Di Era Reformasi; Studi Melalui Pendekatan Sosiologis. Tesis, Banda Aceh, Pasca Sarjana Iain Ar-Raniry.

Ismuha. 1987. Peranan Ulama dalam Program KB di Aceh, Majalah Sinar Darussalam, no. 162-163.

.1982. Agama dan Perubahan Sosial. Jakarta : Rajawali Press.

Ishak, Otto Syamsuddin. 2007. Nestapa di Aceh. Banda Aceh: Media Grafika.

Iskandar. 2009. Metodologi Penelitian Kualitatif . Jakarta: Gaung Persada.

Jarahdam I. 1972. Dua Windu Kodam I Iskandar Muda. Banda Aceh: Kodam I Iskandar Muda.

Jindan, Khalid Ibrahim. 1985.The Islamic Theory Of Government According To Ibnu Taymiyah, Terjemahan Masrohim, Teori Politik Islam : Telaah Kritis Ibn Taymiyah Tentang Pemerintahan Islam. Surabaya : Risalah Gusti.

Kamaruzzaman. 2012. Komunikasi Politik Ulama HUDA dalam Penyelesaian Konflik Aceh. Jakarta: Direktorat Jendral Pendidikan Tinggi Islam.

K.I, Braginsky. 1998. Yang Indah, Berfaedah dan Kamal Sejarah Sastra Melayu Dalam Abad 7-19. Jakarta: INIS.

Langen, K.F.H. Van. 1979. Perang Aceh Kisah Kegalauan Snouck Hurgronye, Terj. Gratifipers. Jakarta: Gratifipers.

Mat Piah, Harun, et al. 2002. Traditional Malay Literature. Kuala LuUlama consultative Council in goverment Politics At Lhokseumawer: Dewan Bahasa dan Pustaka.

Nawawi, Hadari\& Kartini, Mini. 1994. Penelitian Kualitatif . Yokyakarta: Gajah Mada University Prees. 
Peter L, Berger\& Thomas, Luckmann. 1990. The Social Construction of Reality: A Treatise the Sociology of Knowledge. 1966. diterjemahkan menjadi Tafsir Sosial atas Kenyataan (Sebuah Risalah tentanag Sosiologi Pengetahuan). LP3ES.

Pemda Kota Lhokseumawe. 2012. Aceh Utara Dari Kerajaan Samudera Pasai Ke Era Industrialisasi. Lhokseumawe: Dinas Informasi dan Komunikasi.

Qadir, Tijani Abdul. 2001. Ushul Al-Fikr Al-Siyasiy Fi Alquran al-Karim. Jakarta: Gema Insani Press.

Rusyd, Ibnu. Bidayat al-Mujtahid, juz I, Semarang: Toha Putera, t.t.

Said, Muhammad. 1961. "Aceh Sepanjang Abad". Medan, Percetakan dan Penerbitan Waspada.

Saleh, Hasan. 1992.Mengapa Aceh Bergolak. Jakarta: Grafiti Press.

Shihab, Muhammad Quraish. 1998. Membumikan Alquran.Bandung: Mizan.

Siegel, James. 1969. T. The Rope Of God. California University of California Press.

Sufi, Rusdi. 2002. Gerakan Nasionalisme di Aceh. Banda Aceh: Departemen Pendidikan dan Kebudayaan Provinsi Aceh.

Tim Penulis. 2010. Ulama Aceh Dalam Melahirkan Human Resource Di Aceh. Banda Aceh: Yayasan Aceh Mandiri.

Ujong Rimba, Abdullah. 1965. Prasaran Pada Musyawarah Alim Ulama Se Daerah Istimewa Aceh.

Wahid, Abdurrahman. 1988. Paradigma Pengembangan Masyarakat Melalui Pesantren. Majalah Pesantren, Vol 5,

Yacob, Ismail. 1952. Tgk Tjhik Di Tiro (Jakarta: Bulan Bintang.

----1980. "Gambaran Pendidikan di Aceh Sesudah Perang Aceh-Belanda Sampai Sekarang”, dalam buku Ismail Sunni, Bunga Rampai Aceh. Jakarta: Bhatara Karya Aksara.

Zuhairini, et al. 1992.Sejarah Pendidikan Islam. Jakarta: Bumi Aksara. 